Check for updates 2019, 10, 1379

Received 28th May 2019,

Accepted 3rd July 2019

DOI: $10.1039 / \mathrm{c} 9 \mathrm{md} 00297 \mathrm{a}$

rsc.li/medchemcomm
Cite this: Med. Chem. Commun.,

\section{Derivatisation of parthenolide to address chemoresistant chronic lymphocytic leukaemia†}

\author{
Xingjian Li, (D) $\ddagger^{\mathrm{a}}$ Daniel T. Payne, (ID $\ddagger^{\mathrm{a}}$ Badarinath Ampolu, $\S^{\mathrm{b}}$ Nicholas Bland, $\uparrow^{\mathrm{b}}$

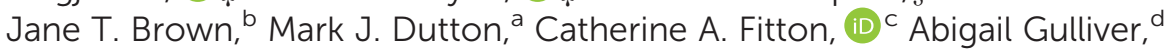 \\ Lee Hale, ${ }^{d}$ Daniel Hamza, ${ }^{\text {b }}$ Geraint Jones, ${ }^{\text {b }}$ Rebecca Lane, ${ }^{\text {b }}$ Andrew G. Leach, (iD e \\ Louise Male, ${ }^{f}$ Elena G. Merisor, ${ }^{b}$ Michael J. Morton, (iD) ${ }^{g}$ Alex S. Quy, (D) ${ }^{a}$ \\ Ruth Roberts, (D) ${ }^{\text {gh }}$ Rosanna Scarll, ${ }^{c}$ Timothy Schulz-Utermoehl, ${ }^{b}$ Tatjana Stankovic, ${ }^{c}$

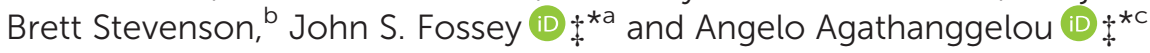

\begin{abstract}
Parthenolide is a natural product that exhibits anti-leukaemic activity, however, its clinical use is limited by its poor bioavailability. It may be extracted from feverfew and protocols for growing, extracting and derivatising it are reported. A novel parthenolide derivative with good bioavailability and pharmacological properties was identified through a screening cascade based on in vitro anti-leukaemic activity and calculated "drug-likeness" properties, in vitro and in vivo pharmacokinetics studies and hERG liability testing. In vitro studies showed the most promising derivative to have comparable anti-leukaemic activity to DMAPT, a previously described parthenolide derivative. The newly identified compound was shown to have prooxidant activity and in silico molecular docking studies indicate a prodrug mode of action. A synthesis scheme is presented for the production of amine 7 used in the generation of $5 \mathrm{f}$.
\end{abstract}

\section{Introduction}

Chronic lymphocytic leukaemia (CLL) is the most common adult leukaemia with $>3000$ new cases in the UK annually. ${ }^{1}$

\footnotetext{
${ }^{a}$ School of Chemistry, University of Birmingham, Edgbaston, Birmingham, West Midlands, B15 2TT, UK. E-mail: j.s.fossey@bham.ac.uk

${ }^{b}$ Sygnature Discovery, The Discovery Building, BioCity, Pennyfoot Street, Nottingham, NG1 1GR, UK

${ }^{c}$ Institute for Cancer and Genomic Sciences, University of Birmingham, Edgbaston, Birmingham, West Midlands, B15 2TT, UK. E-mail: a.agathanggelou@bham.ac.uk ${ }^{d}$ Winterbourne Botanic Garden, University of Birmingham, 58 Edgbaston Park Road, Edgbaston, Birmingham, West Midlands, B15 2RT, UK

${ }^{e}$ School of Pharmacy and Biomolecular Sciences, Liverpool John Moores University, Byrom Street, Liverpool, L3 3AF, UK

${ }^{f} X$-Ray Crystallography Facility, School of Chemistry, University of Birmingham, Edgbaston, Birmingham, West Midlands, B15 2TT, UK

${ }^{g}$ ApconiX Ltd, Alderly Park, Nether Alderly, Cheshire, SK10 4TG, UK

${ }^{h}$ School of Biosciences, University of Birmingham, Edgbaston, Birmingham, West Midlands, B15 2TT, UK

$\dagger$ Electronic supplementary information (ESI) available: General experimental details, aspects relating to cultivation of feverfew, the PTL extraction protocol, synthesis, biological assays computational information and spectrums are detailed in the supporting information. Methods described and references cited therein, ${ }^{45}$ should be referred to in regard of the docking, crystallographic, synthetic and toxicological studies detailed therein. See DOI: 10.1039/c9md00297a

$\$$ AA and JSF are joint last and co-corresponding authors, XL and DTP share joint first authorship. Remaining authors are listed alphabetically, author contributions are described later.

$\S$ Present address: BioMedha Limited, Biocity, Innovation Building, Pennyfoot Street, Nottingham NG1 1GF, UK.

ๆ Present address: Excellerate Bioscience Limited, Discovery Building, Biocity, Pennyfoot Street, Nottingham, NG1 IGR, UK.
} Its variable clinical course ranges from stable indolent disease that does not require treatment, to rapidly progressive disease that necessitates immediate therapeutic intervention. ${ }^{2}$ Clinical response rates to current therapies are strongly influenced by genetic changes including disruption of DNA damage response (DDR) genes ATM and p53. ${ }^{3}$ Tumours with a DDR defect are refractory to chemotherapeutics because they are unable to initiate apoptosis in response to therapy-induced DNA damage. This means tumours with or that develop this DDR defect are not treatable with typical DNA-damaging chemotherapies. Furthermore, since most CLL patients are over the age of 60 (median age $>70$ ) many have comorbidities that preclude the use of aggressive chemotherapeutic regimens. This highlights a need to develop alternative, less aggressive, therapies for the treatment of CLL. ${ }^{4}$

An attractive potential therapeutic is parthenolide (PTL, 1), Fig. 1, upper. PTL (1) is a natural product isolated from feverfew (Tanacetum parthenium) and varietals thereof (Fig. 1, lower), ${ }^{5}$ feverfew being so-named due to its use in traditional remedies. ${ }^{6}$ PTL (1) demonstrates effective and selective antiCLL activity in vitro, ${ }^{7}$ and through its pro-oxidant activity, can target CLL cells independently of their p53 status. ${ }^{8}$ Furthermore, co-authors of this report ${ }^{9}$ are among those who have shown that ATM-deficiency disrupts redox homeostasis, 


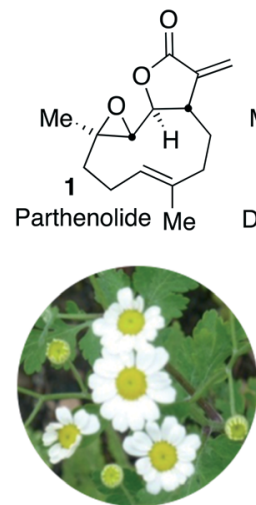

Feverfew

Tanacetum parthenium
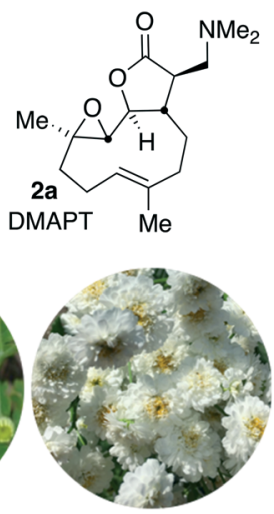

Feverfew

Button-like variety
Fig. 1 Upper: Structure of parthenolide (PTL, 1) and dimethyl aminoPTL (DMAPT) (2a) respectively; lower flowers of feverfew and a button-like (Tanacetum parthenium 'Flore Pleno') feverfew varietal.

increasing further the sensitivity of this DDR-defective subtype of CLL to PTL. ${ }^{10}$ In addition to inducing oxidative stress, PTL has been shown to target tumour cells by suppressing pro-survival and proliferation signalling through the NF- $\kappa$ B pathway, ${ }^{11}$ by inhibiting JAK-STAT kinase activity and thereby preventing STAT-mediated transcription of antiapoptotic genes and by inhibiting DNMT1 and HDACs leading to activation of epigenetically silenced tumour suppressor genes. ${ }^{12}$ Furthermore, through inhibition of NF- $\kappa \mathrm{B}$, PTL is able to reverse resistance to a number of chemotherapeutics including paclitaxel, oxaliplatin, doxorubicin and metoxantrone. ${ }^{13}$ Despite numerous beneficial anti-tumour activities demonstrated in vitro, the clinical utility of PTL is limited by its poor bioavailability and pharmacokinetics. ${ }^{14}$

Crooks and co-workers pioneered the derivatisation of PTL and identified a promising candidate for the treatment of acute myeloid leukaemia (AML), ${ }^{15}$ a dimethyl amino-PTL (DMAPT) derivative, compound $2 \mathrm{a}$ depicted in Fig. 1.14,16 This derivative of PTL (1), DMAPT (2a) and related compounds, have found utility across different diseases with activities against a range of cancer-types reported. ${ }^{16 u}$ PTL has been shown to induce oxidative stress in cancer cells, ${ }^{17}$ and recently DMAPT (2a) was confirmed to induce oxidative stress in CLL cells. ${ }^{9}$ There are a number of reports on the use and derivatisation of PTL, with a view to addressing various cancer types, ${ }^{16 z, 18}$ but the only PTL derivative to be applied to CLL remains compound $2 a^{19}$ Previous studies have used molecular docking to investigate 1 and 2 a which have suggested that interaction with IKK $\beta$ is a plausible mechanism for their action against haematological and solid tumours. ${ }^{18 g}$

It is reasoned that retro-Michael-type chemistry, that reveals PTL at the site of interest, may be at the origin of the activity of amino-PTL derivatives, meaning amino-PTL derivatives (such as 2a) serve as excellent prodrugs for PTL delivery. ${ }^{16 a c, a d}$ Our interest in drug-like nitrogen-containing motifs $^{20}$ prompted us to investigate analogues of DMAPT (2a) in the search for increased activity, favourable pharmacokinetic properties and minimal toxicological burdens, with the ambition of addressing drug-resistant CLL in elderly patients who may suffer more intensely from adverse effects of other therapies. Herein a synthesis cascade to explore the SAR of PTL derivatives is described and findings pertaining to these aims presented.

\section{Results and discussion}

\section{Source of Parthenolide}

Since 2013 feverfew and varietals have been cultivated at Winterbourne House and Garden, ${ }^{21}$ a UK visitor attraction, museum and heritage centre adjunct to the University of Birmingham campus (UK), located $52.4527^{\circ} \mathrm{N}$. Annual crops of plant material have been obtained (Fig. 2), and PTL extracted. Plants in the late stage of flowering were found to contain the highest extractable content of PTL.

An extraction procedure previously reported by co-authors of this report was used (detailed in $\left.\mathrm{ESI}^{\dagger}\right)^{9}$ to access recrystalised, analytically pure, PTL (1), (see ESI $\dagger$ ).

\section{Derivatisation of parthenolide}

The addition of nucleophilic primary and secondary amines to PTL has been reported to proceed with high diastereoselectivity via a conjugate addition to the exocyclic Michael acceptor double bond part of the lactone unit. ${ }^{14,16 a, 18 f, 22}$ The high selectivity for reaction of nucleophilic amines at the $\alpha, \beta$-unsaturated lactone provides evidence of the compatibility of the epoxide motif contained within PTL and its derivatives thus obtained within a drug discovery programme. That is, epoxides display unwanted reactivity towards nucleophiles, and when this reactivity is unleashed in vivo offtarget effects can render them undesirable motifs in medicinal chemistry. ${ }^{23}$ In related research, Long et al. reported the semi-synthesis of PTL and its cyclopropyl (in place of the epoxide part) analogue, ${ }^{24}$ the epoxide-free analogue was more stable to acid-mediated degradation, showing there may be scope to improve the drug-like properties of PTL

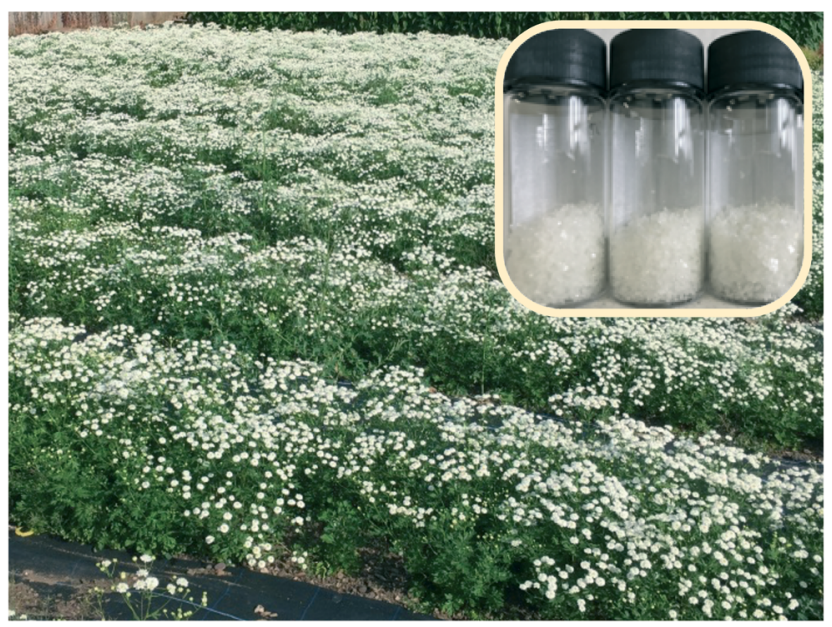

Fig. 2 Feverfew cultivation effort, Winterbourne Botanic Garden, prior to harvesting feverfew; (inset) recrystallised PTL 1. 
analogues by further scaffold manipulation (although that was not probed herein).

Taking advantage of the ease of derivatisation of the lactone part of parthenolide a small initial library of amino (and related) PTL derivatives was generated using an established synthetic protocol (Scheme 1 - conditions $i$ and Fig. 3), resulting in the isolation of compounds $2 \mathbf{a}-\mathbf{d}, 3,4 \mathbf{a}-\mathbf{d}, 5 \mathbf{a}-\mathbf{c}$ and $6 \mathbf{a} \& \mathbf{b}$. Following the successful synthesis of this small collection of PTL derivatives (Scheme 1 - conditions $i$ ), and in order to rapidly expand the library of amino-PTL derivatives available, a more high-throughput approach that allows for a library of products to be created with a range of functionalities and desirable drug-like properties was sought. ${ }^{25}$

Under slightly modified conditions from those previously employed, ${ }^{9,26}$ PTL was reacted with 120 primary or secondary amines that were selected based on calculated properties of the potential products. Used as supplied or obtained (whether neutral or as salts thereof) the amines reacted with PTL 1 in ethanol (Scheme 1 - conditions $i$ ) or in DMSO (20\%) /methanol (80\%) in the presence of Hünig's base (Scheme 1 conditions ii).

The reaction mixtures were filtered and purified by reverse-phase HPLC of the 120 attempted synthesise, 76 successfully delivered products of sufficient purity (ideally $>85 \%$ purity; 65 of which were obtained in $>95 \%$ purity), as judged by HPLC or proton NMR spectroscopy). The materials obtained (shown in Fig. 3) were thus deemed suitable to progress to in vitro activity screening for anti CLL activity. Of the 76 compounds successfully synthesised and progressed to in vitro screening eleven have been previously reported elsewhere in the peer reviewed or patent literature, namely: $2 \mathrm{a},{ }^{16 a f} 2 \mathrm{~b},{ }^{14} 2 \mathrm{c},{ }^{14,16 a} 3,{ }^{16 a, w, 27} 4 \mathbf{a}^{14} 4 \mathrm{c},{ }^{16 a} 4 \mathrm{~d},{ }^{28} 5 \mathrm{a},{ }^{14,16 w, 27-29}$ $5 \mathbf{b},{ }^{14,27-29} 5 \mathbf{c}^{27 b, 29 b}$ and $6 a^{16 y}$

\section{Anti-chronic lymphocytic leukaemia activity}

Defective p53-signalling increases genomic instability and drives tumour progression. A high frequency of p53 inactivation is found in relapsed, treatment-resistant, high risk

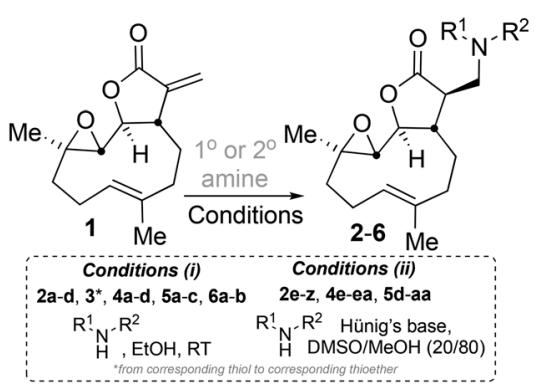

Scheme 1 Synthesis of PTL derivatives 2 (tertiary amines), 3 (a thioether), 4 (acyclic secondary amines), 5 (cyclic tertiary amines) and 6 (amino acid derivatives). Two protocols: Conditions (i) - Addition of nucleophile in ethanol at room temperature; conditions (ii) - addition of nucleophile in dimethylsulphoxide/methanol (20/80) with Hünig's base at room temperature. All product $R^{1}$ and $R^{2}$ groups shown in Fig. 3.
CLL. ${ }^{30}$ The MEC1 cell line (obtained from the American type culture collection (Manassas, VA 20110 USA) expresses a mutated form of p53 and as previously shown, is resistant to clinically relevant DNA-damaging agents such as cyclophosphamide and is therefore representative of treatment-refractory, progressive CLL for which there is an urgent unmet clinical need. ${ }^{31}$ The in vitro antileukaemic activity of the PTLderivatives against the MEC1 CLL cell line was determined using the alamarBlue ${ }^{\circledR}$ (ThermoFischer Scientific) assay and the results are summarised in Table S2. $\dagger^{32}$ Among the active compounds 2c, 2d, 2e, 2f, $2 \mathrm{~g}, 2 \mathrm{j}$, 2aa, 5a, 5b, 5d, 5e, 5f, 5h, $5 \mathrm{ab}$ and $6 \mathrm{~b}$ (Table S2, $\dagger$ entries 4 to 8, 11, 12, 29, 62, 63, 65 to $67,69,89$ and 91 respectively) gave $\mathrm{EC}_{50}$ values $<15 \mu \mathrm{M}$. Owing to resource availability a subset of up to ten of these compounds was prioritised for further investigation. Compounds $2 d, 2 e, 2 j, 2 a a, 5 a, 5 d, 5 e, 5 f, 5 a b$ and 6 b were selected on the basis of reasons including ease of synthetic access, diversity across the chemical space probed and novelty. Those prepared under conditions (i) Scheme 1 (2d, 5a and $6 \mathbf{b})$ were available on a scale and in a purity to directly permit followup studies, whereas compounds prepared under conditions (ii) Scheme 1 were prepared on a small scale so were resynthesised. These seven compounds (2e, 2j, 2aa, 5d, 5e, 5f and $5 \mathrm{ab}$ ) were isolated on $>30 \mathrm{mg}$ scale in high purity and progressed to more following studies.

\section{In vitro DMPK}

Compounds 2d, 2e, 2f, 2g, 2j, 2aa, 5a, 5d, 5e, 5f, 5ab and 6 b were subjected to in vitro DMPK testing. Seven of the ten PTL derivatives (2e, 5a, 5b, 5d, 5f, 5ab and 6b) exhibited greater than two hours stability in aqueous solution and were retained for further investigation. The other three $(2 \mathbf{d}, 2 \mathbf{j}$ and 2aa) were not retained for further investigation due to poor stability ( $T_{1 / 2}$ at $\mathrm{pH}$ 7.4: 13, 107 and $76 \mathrm{~min}$, Table 1 , entries 1,3 and 4 respectively). One obvious aspect contributing to observed stability is the propensity for PTL derivatives of this type to undergo a retro-amination (reverse-Michael-type mechanism), indeed this reverse reaction is often claimed as a pro-drug mode of action. ${ }^{29 a, 33}$ Whether poor stability in this test is as a result of retro-amination or any other process was not determined, either way the compound of interest does not survive long enough in solution to be retained for further study. It is a reasonable assertion that activity observed for these unstable compounds could well be ascribed to free PTL generated rapidly in the assay.

Microsomal and hepatocyte stability assays are in vitro ADME assays used to determine metabolic stability of compounds through measuring intrinsic clearance $\left(\mathrm{CL}_{\mathrm{int}}\right)$ by liver microsomes or by liver hepatocytes. Compounds $2 \mathbf{e}, 5 \mathbf{d}, 5 \mathbf{e}$ and 5ab (Table 1, entries 2, 6, 7 and 9) exhibited $\mathrm{CL}_{\text {int }}$ of $>100 \mu \mathrm{L} \mathrm{min}{ }^{-1} \mathrm{mg}^{-1}$ in the microsomal stability assay indicating rapid clearance and as such, were removed from further investigation. Compounds $\mathbf{5 a}, \mathbf{5 f}$ and $\mathbf{6 b}$ displayed the lowest microsomal intrinsic clearances, $19 \mu \mathrm{L}, 18 \mu \mathrm{L}$ and 9 $\mu \mathrm{L} \min ^{-1} \mathrm{mg}^{-1}$, respectively (Table 1 , entries 5, 8 and 10) and 


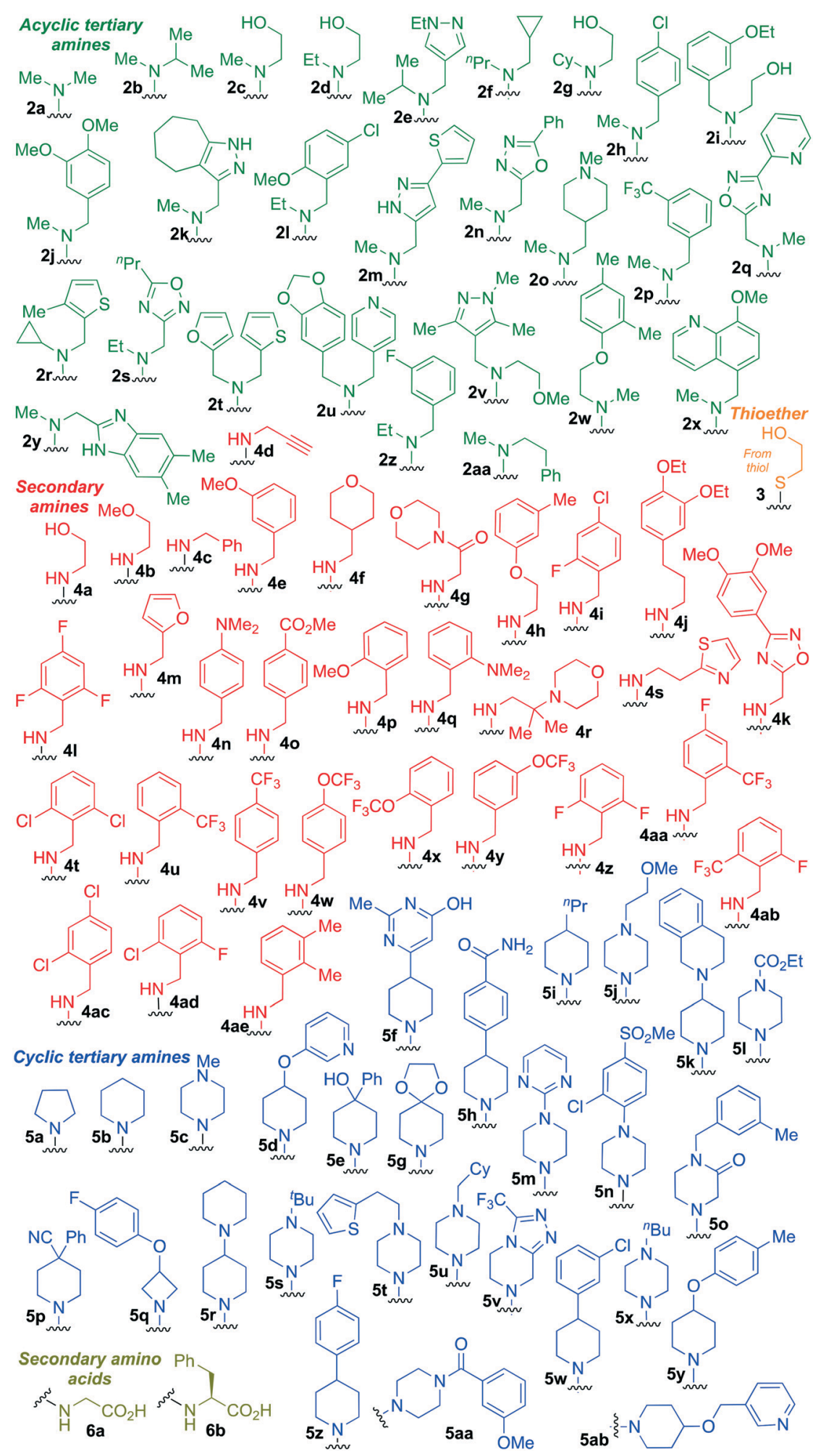

Fig. 3 Summary of PTL derivatives' amine (and one thioether) parts, prepared according to Scheme 1.

were therefore retained for further study. ${ }^{34}$ As a secondary screen for metabolic stability, compounds $5 \mathrm{a}, \mathbf{5 f}$ and $\mathbf{6 b}$ were subjected to the hepatocyte stability assay and this confirmed their suitability for progression to the Caco-2 permeability assay (Table 1, entries 5, 8 and 10). In order to determine the likelihood of the retained compounds being suitable for oral dosing a Caco-2 permeability assay, which predicts intestinal permeability and drug efflux, was conducted. ${ }^{35}$ Compounds 5a and $5 f$ (Table 1, entries 5 and 8) gave efflux ratios close to unity (1.0 and 1.1 respectively), whereas compound $6 \mathbf{b}$ 
Table 1 Screening cascade for favourable drug-like properties of the ten most promising compounds ([-] indicates not tested)

\begin{tabular}{|c|c|c|c|c|c|c|c|c|c|c|c|}
\hline \multirow[b]{2}{*}{ Entry } & \multirow[b]{2}{*}{ Compound } & \multirow[b]{2}{*}{ 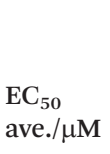 } & \multirow[b]{2}{*}{$\begin{array}{l}\text { LipE } \\
\text { pEC }_{50}-\operatorname{clog} P\end{array}$} & \multirow{2}{*}{$\begin{array}{l}\text { Stability } \\
\mathrm{pH} 7.4 \\
T_{1 / 2} / \mathrm{min}\end{array}$} & \multicolumn{2}{|c|}{$\begin{array}{l}\text { Microsomal } \\
\text { stability (mouse) }\end{array}$} & \multicolumn{2}{|c|}{$\begin{array}{l}\text { Hepatocyte stability } \\
\text { (mouse) }\end{array}$} & \multicolumn{3}{|c|}{$\begin{array}{l}\text { Caco-2 pH } 7.4 \text { mean Papp } \\
\left(10^{-6} \mathrm{~cm} \mathrm{~s}^{-1}\right)\end{array}$} \\
\hline & & & & & A to $B$ & A to $B$ & $\begin{array}{l}\mathrm{CL}_{\text {int }} / \mu \mathrm{L} \min ^{-1} \\
\text { per million cells }\end{array}$ & $\begin{array}{l}T_{1 / 2} / \\
\min \end{array}$ & A to $B$ & B to $\mathrm{A}$ & Efflux ratio \\
\hline 1 & & 4.7 & 3.31 & 13 & - & - & - & - & - & - & - \\
\hline 2 & & 5.6 & 1.61 & $>120$ & 828 & 2 & - & - & - & - & - \\
\hline 3 & & 5.6 & 1.48 & 107 & - & - & - & - & - & - & - \\
\hline 4 & & 5.9 & 2.52 & 76 & - & - & - & - & - & - & - \\
\hline 5 & & 7.7 & 2.35 & $>120$ & 19 & 75 & 22.0 & 65.0 & 15.9 & 16.2 & 1.0 \\
\hline 6 & & 5.4 & 2.48 & $>120$ & 251 & 6 & - & - & - & - & - \\
\hline 8 & & 7.7 & 3.69 & $>120$ & 18 & 77 & 22.0 & 64.0 & 2.7 & 2.8 & 1.1 \\
\hline 9 & & 7.6 & 2.29 & $>120$ & 128 & 11 & - & - & 10.9 & 9.1 & 0.8 \\
\hline 10 & & 13.5 & 3.66 & $>120$ & 9 & 160 & 16.0 & 88.0 & 1.5 & 4.2 & 2.7 \\
\hline
\end{tabular}

(Table 1, entry 10) gave an efflux ratio of 2.7. Thus, compounds $5 \mathrm{a}$ and $\mathbf{5 f}$ were retained and selected for in vivo pharmacokinetic studies.

The parameter lipophilic ligand efficiency (LipE) allows activity of a compound in a given assay to be tensioned against the lipophilicity of the compound. The LipE parameter has become increasingly useful and important in medicinal chemistry drug discovery decision making. ${ }^{36}$ LipE allows the quality of hits to be compared, i.e. deconvolution of activity arising due to better chemistry away from increased activity due to enhancement in lipophilicity alone. It has been claimed that consideration of LipE alongside other 
chemoinformatic parameters in a drug discovery programme can result in the identification of compounds with superior in vivo properties. ${ }^{37}$ As such the calculated $\log P$ values (see Table S2 $\dagger$ ) were in determination of the LipE for the active compounds detailed in Table 1. Notably, the two compounds identified as superior through the conducted screening cascade of this manuscript (5a and $\mathbf{5 f}$ ) have the same $7.7 \mu \mathrm{M}$ $\mathrm{EC}_{50}\left(\mathrm{pEC}_{50}\right.$ 5.11) values against the MEC1 cell line, whereas the calculated $\log P$ values differ by more than one $\log$ unit 2.76 versus 1.42 (respectively). Thus, the corresponding LipE values of 2.35 versus 3.69 for 5 a and $5 \mathbf{f}$ respectively in the probed MEC1 cell line assay (Table 1, entries 5 and 8) reveal that whilst compound $\mathbf{5 f}$ has an equivalent activity to $\mathbf{5 a}$, its activity may arise from advantageous chemical features and not from lipophilicity alone. ${ }^{38}$ Coupled with the data presented in Table $\mathrm{S} 2, \dagger$ consideration of the LipE indicates compound $5 \mathbf{f}$ to offer a potential advantage in a drug discovery programme.

\section{In vivo pharmacokinetics}

In order to determine $\mathbf{5 a}$ and $\mathbf{5 f}$ are suitable for use as pharmaceutical agents their pharmacokinetic (PK) parameters were next probed. A murine intravenous PK study of compounds $5 \mathrm{a}$ and $5 \mathrm{f}$ at $1.0 \mathrm{mg} \mathrm{kg}{ }^{-1}$ was conducted and their concentrations in blood were measured with time (Fig. 4(a)i and (b)i and Table 2).

Unlike the similarity between in vitro intrinsic clearance between 5a and $5 \mathbf{f}$ (Table 1), the in vivo clearance of 5a was nearly four times that of $5 f$ (207 versus $58 \mathrm{~mL} \mathrm{~min}{ }^{-1} \mathrm{~kg}^{-1}$, Table 2). The plasma half-life $\left(T_{1 / 2}\right)$ of $\mathbf{5 f}$ was approximately twice that of $5 \mathrm{a}$ (1.14 versus 0.66 hours, Table 2 ), and the total body exposure to $\mathbf{5 f}$ was more than three times greater than 5a (289 versus $80.5 \mathrm{ng} \mathrm{h} \mathrm{mL}^{-1}$, Table 2).

The in vivo oral bioavailability of compounds $5 \mathbf{a}$ and $\mathbf{5 f}$ was compared in a murine PK study at $10 \mathrm{mg} \mathrm{kg}^{-1}$ (Fig. 4(a)ii and (b)ii and Table 2). In keeping with the intravenous findings, the murine PO half-life of $\mathbf{5 f}$ was twice as long as $\mathbf{5 a}$ (1.0 versus 0.5 hours, Table 2 ) and the $C_{\max }$ attained by $5 \mathbf{f}$ was approximately $40 \%$ higher than that achieved by 5 a $(404$

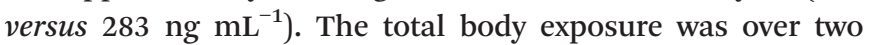
times greater for 5f than 5a (1696 versus $711 \mathrm{ng} \mathrm{h} \mathrm{mL} \mathrm{mL}^{-1}$, Table 2), indicating superior bioavailability. Compound $\mathbf{5 f}$ was therefore identified as a promising potential new agent with desirable pharmacological properties towards a therapy for drug-resistant CLL.

\section{Comparison of the activity of $5 f$ with 1 (PTL) and 2a (DMAPT)}

Following the identification of $\mathbf{5 f}$ as the most promising drug-like derivative of PTL from the aforementioned parallel/
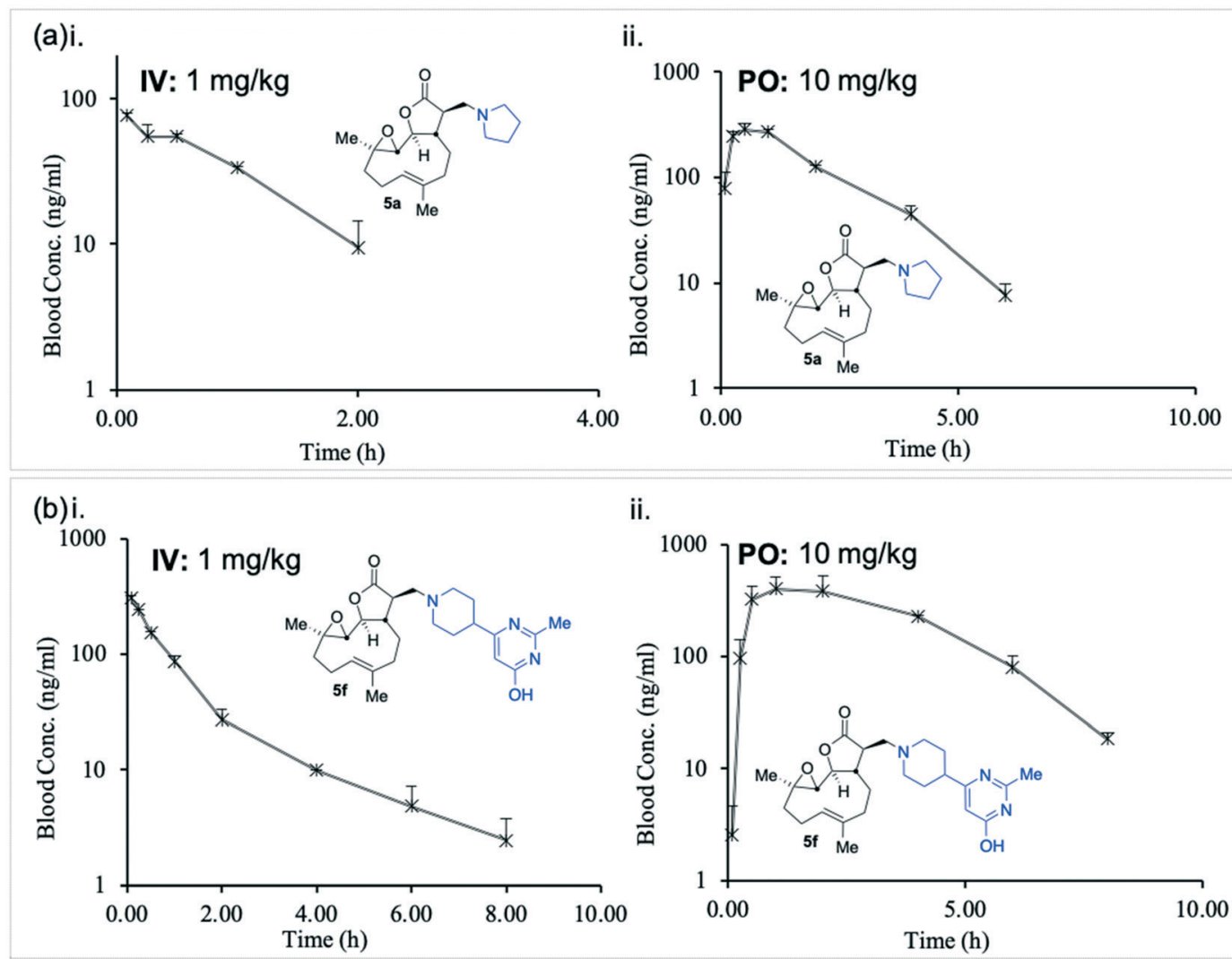

ii.

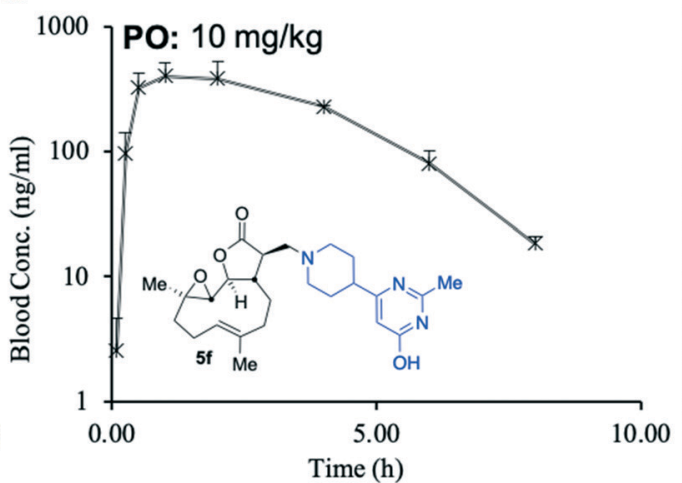

Fig. 4 Graphical representation of murine in vivo pharmacokinetic study, concentrations of $5 \mathrm{a}$ (a) and $5 \mathrm{f}(\mathrm{b})$ i. IV (1 $\left.\mathrm{mg} \mathrm{kg}^{-1}\right)$; ii. PO (10 mg kg $\left.{ }^{-1}\right)$. Data summarised in Table 2. 
Table 2 Data obtained from murine in vivo pharmacokinetic study, concentrations of 5 a and $5 f\left(I V\left(1 \mathrm{mg} \mathrm{kg}^{-1}\right)\right.$ and PO (10 mg kg $\left.\left.{ }^{-1}\right)\right)$. Data represented graphically in Fig. 4

\begin{tabular}{|c|c|c|c|c|c|c|c|c|c|c|}
\hline \multirow[b]{2}{*}{ Entry } & \multirow[b]{2}{*}{ Compound } & \multirow[b]{2}{*}{ 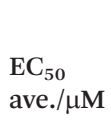 } & \multicolumn{4}{|c|}{ Mouse PK (IV) } & \multicolumn{4}{|c|}{ Mouse PK (PO) } \\
\hline & & & $\begin{array}{l}\mathrm{Cl} / \mathrm{mL} \\
\mathrm{min}^{-1} \mathrm{~kg}^{-1}\end{array}$ & $T_{1 / 2} / \mathrm{h}$ & $\mathrm{VSS} / \mathrm{L} \mathrm{kg}^{-1}$ & $\begin{array}{l}\text { UC (0-inf)/ng } \\
\text { h mL }^{-1}\end{array}$ & $T_{\max } / \mathrm{h}$ & $\begin{array}{l}C_{\max } / \mathrm{ng} \\
\mathrm{mL}^{-1}\end{array}$ & F\% & $\begin{array}{l}\text { UC (0-inf)/ng } \\
\mathrm{h} \mathrm{mL}^{-1}\end{array}$ \\
\hline
\end{tabular}

high-throughput screening, the anti-leukaemic activity of $\mathbf{5 f}$ was tested once more and compared directly with that of PTL (1) and DMAPT (2a), which serve as comparators and positive controls. Fig. 5(a) shows that the activity of $5 \mathbf{f}(n=5)\left(\mathrm{EC}_{50}=\right.$ $4.5 \mu \mathrm{M})$ was not significantly different to the activity of PTL $(n=5)$ or DMAPT $(n=5)$ with $\mathrm{EC}_{50}$ values of $6.2 \mu \mathrm{M}$ and 5.6 $\mu \mathrm{M}$, respectively (Table $\mathrm{S} 2, \dagger$ entries 1 and 2 ) indicating that it has comparable activity with the parent and literature compounds ( 1 and $2 \mathrm{a}$ respectively). Pre-treatment with $\mathrm{N}$-acetylcysteine (NAC) abrogated activity demonstrating that similar to PTL and other derivatives, $\mathbf{5 f}$ is a pro-oxidant and induces cell death through induction of oxidative stress, Fig. 5(b). Furthermore, in silico modelling suggests that $\mathbf{5 f}$ is likely to function as a pro-drug and deliver PTL to also inhibit IKK $\beta$ and NF- $\kappa$ B, Fig. S3 and S4.†

\section{In vitro hERG liability testing}

Early toxicological screening is an important step in derisking drug discovery programmes and is increasingly accessible. ${ }^{39}$ Since an unacceptable human ether a go-go related gene (hERG) liability is an all too common reason for failure at the candidate selection stage, a hERG assay was conducted to ensure the compounds being developed did not carry this liability. ${ }^{40}$

Three PTL derivatives (2a, 5a and 5f) were tested for inhibition of the hERG $\mathrm{K}^{+}$channel (against cisapride as a positive control) using IonWorks patch clamp electrophysiology. In assessment of any hERG liability, compound 5a was compared to compound $\mathbf{5 f}$ which had already been identified as a superior pre-candidate compound; whilst 2a (DMAPT) is specifically not the focus of this manuscript it was deemed appropriate to contrast any hERG liability of this the literaturereported anti-AML compound. ${ }^{16 a f}$ Eight-point concentrationresponse curves were generated using three-fold serial dilutions from a maximum final test concentration of $100 \mu \mathrm{M}$, results are summarised in Fig. S6. $\dagger$

The three PTL derivatives compared (2a, $5 \mathbf{a}$ and $\mathbf{5 f}$ ) in this hERG liability assay all performed well displaying $\mathrm{IC}_{50}$ values $>100 \mu \mathrm{M}$ (i.e. inhibition of less than $50 \%$ at the top $100 \mu \mathrm{M}$ test concentration). At said top $(100 \mu \mathrm{M})$ test concentration the novel compound 5 f elicited only a $24 \%$ inhibition, whereas compounds 2 a and 5 a performed slightly less well with inhibitions of 40 and 45\% (Fig. S6 and Table S4, $\dagger$ entries 1 and 2) respectively. Thus, hERG liability study, confirms PTL derivatives tested to represent a minimal risk according to results of the in vitro tests conducted. Among the
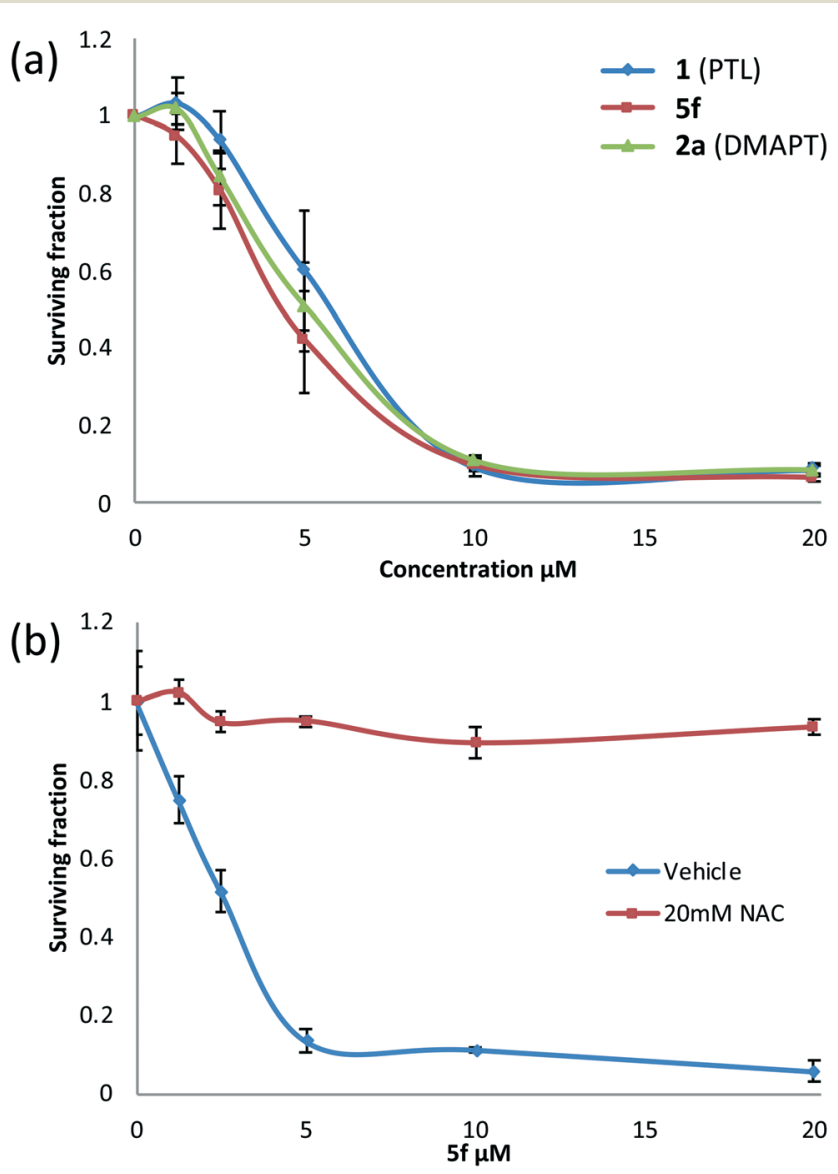

Fig. 5 Concentration versus activity plots (alamarBlue ${ }^{\circledR}$ assay) showing (a) anti-leukaemic activity of $\mathbf{5 f}$ versus PTL and DMAPT in MEC1 cells and (b) the effect of NAC pretreatment on the activity of $\mathbf{5 f}$. 


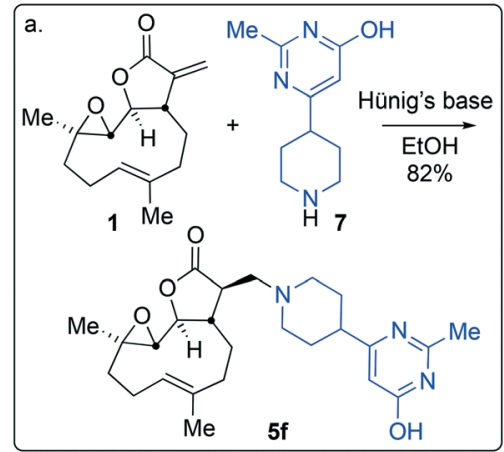

b. $\mathrm{CO}_{2} \mathrm{H} \quad \mathrm{CO}_{2} \mathrm{H}$ i, $\mathrm{CDI}, \mathrm{THF} ; \quad \mathrm{CO}_{2} \mathrm{Et}$
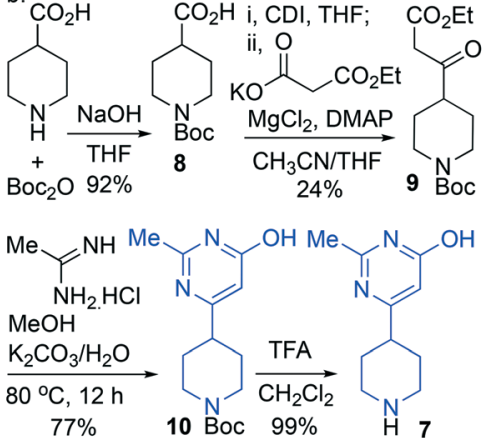

Scheme 2 (a) The optimised synthesis of $\mathbf{5 f}$; (b) the designed and executed plan for the synthesis of the required amine 7 .

compounds tested $\mathbf{5 f}$ displayed the lowest hERG liability and was flagged as inactive (Table $54, \uparrow$ entry 3 ) confirming compound $5 \mathbf{f}$ as the most promising lead from the studies conducted herein.

\section{Synthetic access to compound $5 f$}

Through identification of compound $\mathbf{5} \mathbf{f}$ as the resulting precandidate from the described screening cascade in earlier sections the requirement to provide more material for this and onwards studies presented a new and unexpected prob- lem. Whilst it was possible to synthesise compound $\mathbf{5 f}$ in $83 \%$ isolated yield in high purity via a hybrid of the earlier mentioned protocols (Scheme 2a), the availability of amine 7 caused some issues, namely during the course of this work resupply of amine 7 (or salts thereof) became challenging. This uncertain supply chain led us to probe the synthesis and set about synthesising our own material. Despite the compound being listed in the catalogues of numerous suppliers, a literature search (SciFinder) revealed very few instances of the motif occurring in the peer reviewed ${ }^{41}$ or patent literature. ${ }^{42}$ The synthesis of amine 7 had not, to the best of our knowledge at the time of writing this report, been reported in the peer reviewed literature. As such a synthetic protocol was proposed (Scheme $2 \mathrm{~b}$ ).

Amine 7 was successfully prepared as follows: 4-Piperidinecarboxylic acid was $\mathrm{N}$-Boc protected to deliver 8 in $92 \%$ yield. ${ }^{43}$ In order to confidently assign the NMR spectra of compound $8 \mathrm{~J}$-MOD, HSQC and ${ }^{1} \mathrm{H}^{-1}{ }^{1} \mathrm{H}$ COSY were helpful, particularly in establishing that a broad resonance in the proton-decoupled ${ }^{13} \mathrm{C}$ NMR spectrum, centred on $42.8 \mathrm{ppm}$, corresponds to the ring-carbons bonded to nitrogen. The carboxylic acid of 8 was converted to the corresponding ethyl-3keto-propanoate 9 in $24 \%$ yield. Conversion of 9 to the $N$-Boc protected congener 10, was achieved by treatment with acetamidine hydrochloride and potassium carbonate, furnishing 10 in $77 \%$ yield. Treatment with trifluoroacetic acid delivered desired compound 7 in $99 \%$ yield for the Bocdeprotection step (scale $200 \mathrm{mg}, 17 \%$ over four linear steps). Thus, evidencing accessibility of amine 7 and with it in hand, it was timely to probe any activity arising from the amine alone. MEC1 sensitivity to $\mathbf{1}, \mathbf{5 f}$ and 7 was compared in parallel using the alamarBlue ${ }^{\circledR}$ assay (Fig. 6). $\mathrm{EC}_{50}$ values were determined (CalcuSyn Version 2.11, BIOSOFT) for $\mathbf{1}(3.6 \mu \mathrm{M} \pm 0.46)$ and $5 \mathrm{f}(4.3 \mu \mathrm{M} \pm 0.60)$. In contrast, an $\mathrm{EC}_{50}$ could not be determined for amine 7 since MEC1 cells were unaffected by equivalent concentrations of it indicating that 7 is not a source of cytotoxicity observed in this assay. A pre-peer-

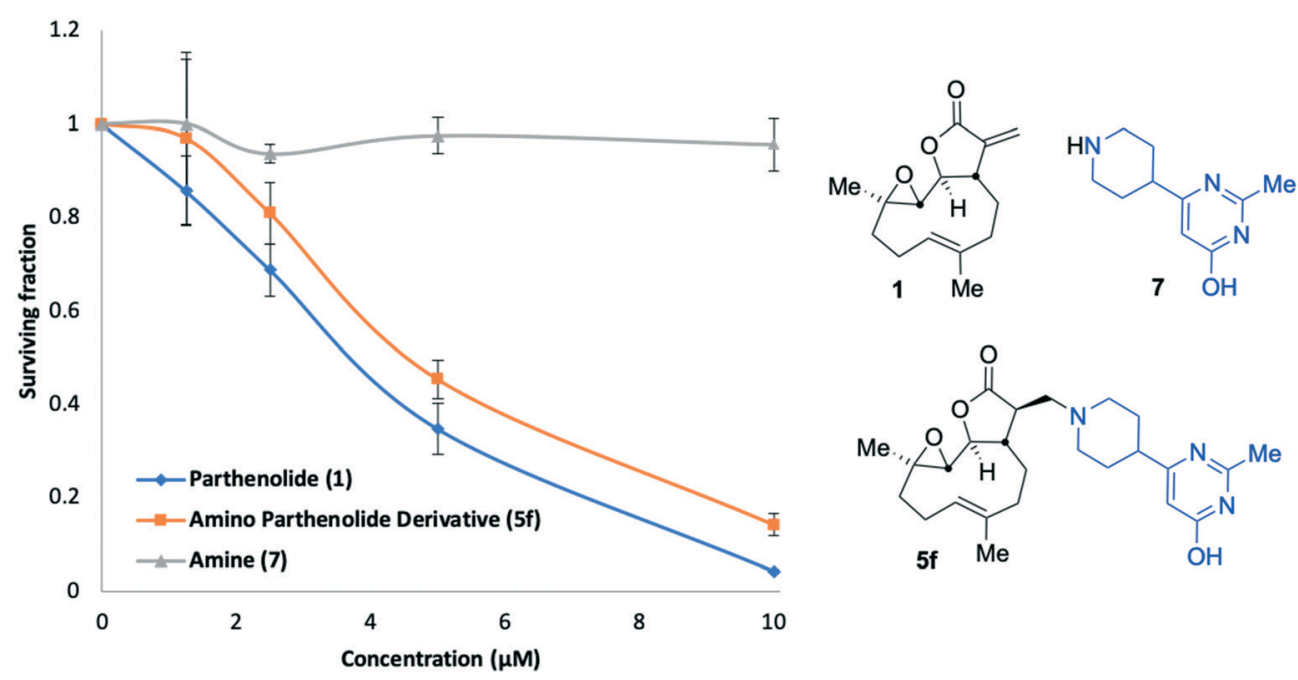

Fig. 6 Concentration versus activity plots (alamarBlue ${ }^{\circledR}$ assay) showing anti-leukaemic activity of 1 (PTL), $5 f$ and amine 7 in MEC1 cells. 
reviewed preprint of this article was deposited and may be viewed elsewhere. ${ }^{44}$

\section{Conclusions}

The cultivation of feverfew, from which PTL 1 was extracted, was described. The isolation of PTL (1) permitted the synthesis of a library of derivatives, through smooth 1,4-addition to PTL's exocyclic Michael-acceptor $\mathrm{C}=\mathrm{C}$ double bond. The library thus synthesised displayed good coverage of medicinally relevant chemical space. The compounds synthesised were tested for activity against the MEC1 CLL cell line. These compounds showed no particular trend in activity across the window of already acceptable medicinal chemistry parameters, such as $\mathrm{p} K_{\mathrm{a}}, \operatorname{cLog} D, \operatorname{cLog} P$, TPSA, Fsp ${ }^{3}$ and molecular weight. The DMPK screening cascade described identified compound $\mathbf{5 f}$ as the most promising from activity, safety profile and ADME property stand-points. Direct in vitro comparison showed $\mathbf{5 f}$ exhibited comparable activity to DMAPT against the MEC1 cell line and pre-treatment with NAC suggested a pro-oxidant mechanism of action. Molecular docking studies with components of the NF- $\kappa$ B pathway also support a pro-drug mode of action of the compounds involving release of $\mathbf{1}$ and covalent interaction with one or more proteins involved in that pathway. This is partially supported by the lack of activity of the thioether adduct, compound 3 , that is far less prone to undergo a reverse reaction to reveal 1, although lack of activity cannot be ascribed to this phenomenon alone. Taken together, these findings confirm $\mathbf{5 f}$ as a promising motif for further study and elaboration towards treatments for drug resistant CLL.

\section{Notes}

Ruth Roberts and Michael J. Morton are co-founders and codirectors of Apconix Ltd, an integrated toxicology and ion channel company that provides expert advice on nonclinical aspects of drug discovery and drug development to academia, industry and non-for-profit organisations. The remaining authors declare no competing interests.

\section{Author Contributions}

All authors contributed critically to devising and executing this research. A detailed description of the specific contribution of each author is given in the ESI. $\dagger$

\section{Conflicts of interest}

There is no conflict of interest to declare.

\section{Acknowledgements}

AA and JSF are grateful for the support of internally allocated MRC Confidence in Concepts (14/15) and EPSRC (ISF 2012) pump-priming grants. The University of Birmingham are thanked for support, not only of the scientists and research facilities but also via Winterbourne House and Garden. Their crucial, critical and extremely valuable support includes the staff who have dedicated time, resources and effort to the cultivation of feverfew and varieties thereof. The CASE network has facilitated cooperation, training and networking opportunities. ${ }^{46}$ Professor Jonathan Frampton (University of Birmingham) is thanked for help throughout and providing support that was crucial at the project initiation stage. The authors thank the ERDF AWM II for support. DTP thanks The School of Chemistry for a studentship. Huy Van Nguyen (University of Birmingham) is thanked for assistance with aspects of experiments conducted in the latter stages. JSF is extremely grateful to the Royal Society Industry Fellowship scheme (2012/R1) and the EPSRC for funding (EP/J003220/1). JSF also acknowledges the importance of the training received through a residential Royal Society of Chemistry Drug Discovery training workshop. Dr. Chi Tsang and Dr. Peter Ashton are thanked for helpful discussions about mass spectrometry. Dr. Cécile S. Le Duff and Dr. Neil Spencer gave advice on aspects of NMR spectroscopy. The laboratory of TS is grateful for the support of Bloodwise (14031). AGL thanks Liverpool John Moores University for support. Dr. Sam Butterworth (University of Manchester, formerly of University of Birmingham), Dr. David Fox (Vulpine Science and Learning) and Dr. John Liddle (GSK) are thanked for advice, mentorship and training through agreements with the University of Birmingham and internal advisory panels. Past and present members of the research group headed by JSF are thanked where appropriate for efforts in harvesting feverfew and extraction of PTL.

\section{References}

1 (a) A. M. Pfeil, P. Imfeld, R. Pettengell, S. S. Jick, T. D. Szucs, C. R. Meier and M. Schwenkglenks, Ann. Hematol., 2015, 94, 421-429; (b) M. Montillo, Leuk. Suppl., 2012, 1, S31.

2 (a) S. A. Parikh, Blood Cancer J., 2018, 8, 93; (b) G. Dighiero and T. J. Hamblin, Lancet, 2008, 371, 1017-1029.

3 (a) P. Baliakas, M. Iskas, A. Gardiner, Z. Davis, K. Plevova, F. Nguyen-Khac, J. Malcikova, A. Anagnostopoulos, S. Glide, S. Mould, K. Stepanovska, M. Brejcha, C. Belessi, F. Davi, S. Pospisilova, A. Athanasiadou, K. Stamatopoulos and D. Oscier, Am. J. Hematol., 2013, 89, 249-255; (b) H. Döhner, S. Stilgenbauer, A. Benner, E. Leupolt, A. Kröber, L. Bullinger, K. Döhner, M. Bentz and P. Lichter, N. Engl. J. Med., 2000, 343, 1910-1916; (c) C. Pepper, T. T. Lin, G. Pratt, S. Hewamana, P. Brennan, L. Hiller, R. Hills, R. Ward, J. Starczynski, B. Austen, L. Hooper, T. Stankovic and C. Fegan, Blood, 2008, 112, 3807-3817.

4 (a) E. P. Stout, M. Y. Choi, J. E. Castro and T. F. Molinski, J. Med. Chem., 2014, 57, 5085-5093; (b) G. Brunhofer-Bolzer, T. Le, N. Dyckmanns, H. A. Knaus, C. Pausz, P. Freund, U. Jäger, T. Erker and K. Vanura, J. Med. Chem., 2015, 58, 1244-1253; (c) H. Chen, P. Song, Y. Diao, Y. Hao, D. Dou, W. Wang, X. Fang, Y. Wang, Z. Zhao, J. Ding, H. Li, H. Xie and Y. $\mathrm{Xu}$, MedChemComm, 2018, 9, 697-704. 
5 (a) A. M. G. Brown, K. C. Lowe, M. R. Davey, J. B. Power, D. W. Knight and S. Heptinstall, Phytochem. Anal., 1996, 7, 86-91; (b) J. Z. Zhou, X. Kou and D. Stevenson, J. Agric. Food Chem., 1999, 47, 1018-1022; (c) M. C. Pasquali, S. Alizai, C. Rostron and M. I. Berry, J. Pharm. Pharmacol., 2005, 57, S72; (d) A. M. L. Seca, A. M. S. Silva and D. C. G. A. Pinto, in Stud. Nat. Prod. Chem., ed. A. U. Rahman, Elsevier, 2017, vol. 52, pp. 337-372; (e) G. babaei, A. Aliarab, S. Abroon, Y. Rasmi and S. G.-G. Aziz, Biomed. Pharmacother., 2018, 106, 239-246.

6 (a) M. J. Biggs, E. S. Johnson, N. P. Persaud and D. M. Ratcliffe, Lancet, 1982, 2, 776; (b) D. M. Hylands, P. J. Hylands, E. S. Johnson, N. P. Kadam and K. D. Macrae, $B r$. Med. J., 1985, 291, 1128; (c) E. S. Johnson, N. P. Kadam, D. M. Hylands and P. J. Hylands, Br. Med. J., 1985, 291, 569-573; (d) E. S. Johnson, N. P. Kadam, D. Anderson, P. C. Jenkinson, R. S. Dewdney and S. D. Blowers, Hum. Toxicol., 1987, 6, 533-534; (e) B. K. Vogler, M. H. Pittler and E. Ernst, Cephalalgia, 1998, 18, 704-708; $(f)$ E. Ernst and M. H. Pittler, Public Health Nutr., 2000, 3, 509-514; $(g)$ M. H. Pittler, B. K. Vogler and E. Ernst, Cochrane Database Syst. Rev., 2000, DOI: 10.1002/14651858.CD002286, CD002286; $(h)$ M. H. Pittler and E. Ernst, Cochrane Database Syst. Rev., 2004, DOI: 10.1002/ 14651858.CD002286.pub2, CD002286; (i) A. Pareek, G. Rathore, M. Suthar and V. Bansal, Pharmacogn Rev., 2011, 103, DOI: 10.4103/0973-7847.79105; $(j)$ M. L. Chavez and P. I. Chavez, Hosp. Pharm., 1999, 34, 436-461.

7 R. P. Wu, T. Hayashi, H. B. Cottam, G. Jin, S. Yao, C. C. N. Wu, M. D. Rosenbach, M. Corr, R. B. Schwab and D. A. Carson, Proc. Natl. Acad. Sci. U. S. A., 2010, 107, 7479.

8 A. J. Steele, D. T. Jones, K. Ganeshaguru, V. M. Duke, B. C. Yogashangary, J. M. North, M. W. Lowdell, P. D. Kottaridis, A. B. Mehta, A. G. Prentice, A. V. Hoffbrand and R. G. Wickremasinghe, Leukemia, 2006, 20, 1073-1079.

9 A. Agathanggelou, V. J. Weston, T. Perry, N. J. Davies, A. Skowronska, D. T. Payne, J. S. Fossey, C. E. Oldreive, W. Wei, G. Pratt, H. Parry, D. Oscier, S. J. Coles, P. S. Hole, R. L. Darley, M. McMahon, J. D. Hayes, P. Moss, G. S. Stewart, A. M. R. Taylor and T. Stankovic, Haematologica, 2015, 100, 1076-1085.

10 C. Cosentino, D. Grieco and V. Costanzo, EMBO J., 2011, 30, 546-555.

11 A. J. Steele, D. T. Jones, K. Ganeshaguru, V. M. Duke, B. C. Yogashangary, J. M. North, M. W. Lowdell, P. D. Kottaridis, A. B. Mehta, A. G. Prentice, A. V. Hoffbrand and R. G. Wickremasinghe, Leukemia, 2006, 20, 1073.

12 (a) J. Wen, K.-R. You, S.-Y. Lee, C.-H. Song and D.-G. Kim, J. Biol. Chem., 2002, 277, 38954-38964; (b) Z. Liu, S. Liu, Z. Xie, R. E. Pavlovicz, J. Wu, P. Chen, J. Aimiuwu, J. Pang, D. Bhasin, P. Neviani, J. R. Fuchs, C. Plass, P.-K. Li, C. Li, T. H. M. Huang, L.-C. Wu, L. Rush, H. Wang, D. Perrotti, G. Marcucci and K. K. Chan, J. Pharmacol. Exp. Ther., 2009, 329, 505.

13 (a) N. M. Patel, S. Nozaki, N. H. Shortle, P. Bhat-Nakshatri, T. R. Newton, S. Rice, V. Gelfanov, S. H. Boswell, R. J. Goulet, G. W. Sledge and H. Nakshatri, Oncogene, 2000, 19, 4159; (b) L. J. Fang, X. T. Shao, S. Wang, G. H. Lu, T. Xu and J. Y.
Zhou, Planta Med., 2010, 76, 258-264; (c) D. Carlisi, A. De Blasio, R. Drago-Ferrante, R. Di Fiore, G. Buttitta, M. Morreale, C. Scerri, R. Vento and G. Tesoriere, Cell Death Discovery, 2017, 3, 17078; (d) D. W. Knight, Nat. Prod. Rep., 1995, 12, 271-276; (e) V. B. Mathema, Y.-S. Koh, B. C. Thakuri and M. Sillanpää, Inflammation, 2012, 35, 560-565.

14 S. Neelakantan, S. Nasim, M. L. Guzman, C. T. Jordan and P. A. Crooks, Bioorg. Med. Chem. Lett., 2009, 19, 4346-4349.

15 M. L. Guzman, R. M. Rossi, X. Li, C. Corbett, D. C. Hassane, T. Bushnell, M. Carroll, E. Sullivan, S. Neelakantan, P. A. Crooks and C. T. Jordan, Blood, 2006, 108, 237.

16 (a) S. Nasim and P. A. Crooks, Bioorg. Med. Chem. Lett., 2008, 18, 3870-3873; (b) R. Shanmugam, P. Kusumanchi, H. Appaiah, L. Cheng, P. Crooks, S. Neelakantan, T. Peat, J. Klaunig, W. Matthews, H. Nakshatri and C. J. Sweeney, Int. J. Cancer, 2011, 128, 2481-2494; (c) G. Lamture, P. A. Crooks and M. J. Borrelli, Drug Dev. Res., 2018, 79, 287-294; (d) M. A. Kennedy, US2018/0099014A1, 2018; (e) R. Wang, P. BhatNakshatri, M. B. Padua, M. S. Prasad, M. Anjanappa, M. Jacobson, C. Finnearty, V. Sefcsik, K. McElyea, R. Redmond, G. Sandusky, N. Penthala, P. A. Crooks, J. Liu, T. Zimmers and H. Nakshatri, Mol. Cancer Ther., 2017, 16, 2747-2758; $(f)$ K. L. Morel, R. J. Ormsby, E. Bezak, C. J. Sweeney and P. J. Sykes, Radiat. Res., 2017, 187, 501-512; ( $g$ ) M. S. Mendonca, W. T. Turchan, M. E. Alpuche, C. N. Watson, N. C. Estabrook, H. Chin-Sinex, J. B. Shapiro, I. E. Imasuen-Williams, G. Rangel, D. P. Gilley, N. Huda, P. A. Crooks and R. H. Shapiro, Free Radical Biol. Med., 2017, 112, 318-326; (h) V. Janganati, P. Crooks, J. Ponder and C. Jordan, WO2017/132528A1, 2017; (i) D. Carlisi, G. Buttitta, R. Di Fiore, C. Scerri, R. DragoFerrante, R. Vento and G. Tesoriere, Cell Death Dis., 2016, 7, e2194; (j) H. Nakshatri, H. N. Appaiah, M. Anjanappa, D. Gilley, H. Tanaka, S. Badve, P. A. Crooks, W. Mathews, C. Sweeney and P. Bhat-Nakshatri, Cell Death Dis., 2015, 6, e1608; (k) A. M. Kempema, J. C. Widen, J. K. Hexum, T. E. Andrews, D. Wang, S. K. Rathe, F. A. Meece, K. E. Noble, Z. Sachs, D. A. Largaespada and D. A. Harki, Bioorg. Med. Chem., 2015, 23, 4737-4745; (l) A. Karmakar, Y. Xu, T. Mustafa, G. Kannarpady, S. M. Bratton, A. Radominska-Pandya, P. A. Crooks and A. S. Biris, RSC Adv., 2015, 5, 2411-2420; $(m)$ V. Janganati, N. R. Penthala, P. A. Crooks and C. T. Jordan, US2015/0133444A1, 2015; (n) S. Bommagani, P. Crooks, N. R. Penthala, V. Janganati, C. T. Jordan and J. Ponder, US2015/ 0203508A1, 2015; (o) E. Viennois, B. Xiao, S. Ayyadurai, L. Wang, P. G. Wang, Q. Zhang, Y. Chen and D. Merlin, Lab. Invest., 2014, 94, 950-965; (p) J. M. Song, X. Qian, P. Upadhyaya, K. H. Hong and F. Kassie, Curr. Cancer Drug Targets, 2014, 14, 59-69; (q) V. Janganati, N. R. Penthala, N. R. Madadi, Z. Chen and P. A. Crooks, Bioorg. Med. Chem. Lett., 2014, 24, 3499-3502; (r) M. T. Yip-Schneider, H. Wu, K. Stantz, N. Agaram, P. A. Crooks and C. M. Schmidt, BMC Cancer, 2013, 13, 194; (s) M. T. Yip-Schneider, H. Wu, R. H. Hruban, A. M. Lowy, P. A. Crooks and C. M. Schmidt, Pancreas, 2013, 42, 160-167; ( $t$ ) P. V. Ramachandran, D. R. Nicponski, H. N. G. Nair, M. A. Helppi, P. D. Gagare, C. M. Schmidt and M. T. Yip-Schneider, Bioorg. Med. Chem. Lett., 
2013, 23, 6911-6914; (u) A. Ghantous, A. Sinjab, Z. Herceg and N. Darwiche, Drug Discovery Today, 2013, 18, 894-905; (v) A. D'Anneo, D. Carlisi, M. Lauricella, R. Puleio, R. Martinez, S. Di Bella, P. Di Marco, S. Emanuele, R. Di Fiore, A. Guercio, R. Vento and G. Tesoriere, Cell Death Dis., 2013, 4, e891; (w) R. Michelle, S. Marcus Tullius, C. Mauro Vicentini, F. Harold Hilarion, S. Luciana, J. Francisco Jaime Bezerra Mendonca, S. Marcelo Sobral da and E. Vicente de Paulo, Lett. Drug Des. Discovery, 2012, 9, 881-890; (x) D. A. Harki and D. Wang, WO2012/145678A1, 2012; (y) S. Zhang and G. Xiong, CN101270102A, 2008; (z) G. Flores-Lopez, D. MorenoLorenzana, M. Ayala-Sanchez, S. Aviles-Vazquez, H. TorresMartinez, P. A. Crooks, M. L. Guzman, H. Mayani and A. Chávez-González, J. Cell. Mol. Med., 2018, 22, 4899-4912; (aa) C. Shi, Y. Wang, Y. Guo, Y. Chen and N. Liu, Oncotarget, 2017, 8, 35009-35018; ( $a b)$ N. R. Penthala, V. Janganati, T. L. Alpe, S. M. Apana, M. S. Berridge, P. A. Crooks and M. J. Borrelli, Bioorg. Med. Chem. Lett., 2016, 26, 5883-5886; (ac) J. K. Hexum, C. M. Becker, A. M. Kempema, J. R. Ohlfest, D. A. Largaespada and D. A. Harki, Bioorg. Med. Chem. Lett., 2015, 25, 2493-2495; (ad) K. Shanmugam, P. Kusumanchi, L. Cheng, P. Crooks, S. Neelakantan, W. Matthews, H. Nakshatri and C. J. Sweeny, Drug Discovery Today, 2010, 15, 322; (ae) R. Peese, Drug Discovery Today, 2010, 15, 322; (af) M. L. Guzman, R. M. Rossi, S. Neelakantan, X. Li, C. A. Corbett, D. C. Hassane, M. W. Becker, J. M. Bennett, E. Sullivan, J. L. Lachowicz, A. Vaughan, C. J. Sweeney, W. Matthews, M. Carroll, J. L. Liesveld, P. A. Crooks and C. T. Jordan, Blood, 2007, 110, 4427-4435.

17 (a) J. Wen, K. R. You, S. Y. Lee, C. H. Song and D. G. Kim, J. Biol. Chem., 2002, 277, 38954-38964; (b) S. Pei, M. Minhajuddin, K. P. Callahan, M. Balys, J. M. Ashton, S. J. Neering, E. D. Lagadinou, C. Corbett, H. Ye, J. L. Liesveld, K. M. O'Dwyer, Z. Li, L. Shi, P. Greninger, J. Settleman, C. Benes, F. K. Hagen, J. Munger, P. A. Crooks, M. W. Becker and C. T. Jordan, J. Biol. Chem., 2013, 288, 33542-33558.

18 (a) M. Shin, A. McGowan, G. J. DiNatale, T. Chiramanewong, T. Cai and R. E. Connor, ACS Omega, 2017, 2, 7267-7274; (b) Z. F. Liu, S. J. Liu, Z. L. Xie, R. E. Pavlovicz, J. Wu, P. Chen, J. Aimiuwu, J. X. Pang, D. Bhasin, P. Neviani, J. R. Fuchs, C. Plass, P. K. Li, C. Li, T. H. M. Huang, L. C. Wu, L. Rush, H. Y. Wang, D. Perrotti, G. Marcucci and K. K. Chan, J. Pharmacol. Exp. Ther., 2009, 329, 505-514; (c) M. Moumou, A. El Bouakher, H. Allouchi, A. El Hakmaoui, A. Benharref, V. Mathieu, G. Guillaumet and M. Akssira, Bioorg. Med. Chem. Lett., 2014, 24, 4014-4018; (d) Z. Yang, B. Kuang, N. Kang, Y. Ding, W. Ge, L. Lian, Y. Gao, Y. Wei, Y. Chen and Q. Zhang, Eur. J. Med. Chem., 2017, 127, 296-304; (e) N. R. Penthala, S. Bommagani, V. Janganati, K. B. Macnicol, C. E. Cragle, N. R. Madadi, L. L. Hardy, A. M. Macnicol and P. A. Crooks, Eur. J. Med. Chem., 2014, 85, 517-525; $(f)$ A. Taleghani, M. A. Nasseri and M. Iranshahi, Bioorg. Chem., 2017, 71, 128-134; (g) V. Janganati, J. Ponder, M. Balasubramaniam, P. BhatNakshatri, E. E. Bar, H. Nakshatri, C. T. Jordan and P. A. Crooks, Eur. J. Med. Chem., 2018, 157, 562-581; (h) A. M. Kempema, J. C. Widen, J. K. Hexum, T. E. Andrews, D. Wang,
S. K. Rathe, F. A. Meece, K. E. Noble, Z. Sachs, D. A. Largaespada and D. A. Harki, Bioorg. Med. Chem., 2015, 23, 4737-4745; (i) J. Long, Y.-H. Ding, P.-P. Wang, Q. Zhang and Y. Chen, Tetrahedron Lett., 2016, 57, 874-877; $(j)$ S. Zimmermann, G. Fouché, M. De Mieri, Y. Yoshimoto, T. Usuki, R. Nthambeleni, J. C. Parkinson, C. van der Westhuyzen, M. Kaiser, M. Hamburger and M. Adams, Molecules, 2014, 19, 3523-3538; $(k)$ Y. Ren, J. Yu and A. Douglas Kinghorn, Curr. Med. Chem., 2016, 23, 2397-2420.

19 S. Hewamana, S. Alghazal, T. T. Lin, M. Clement, C. Jenkins, M. L. Guzman, C. T. Jordan, S. Neelakantan, P. A. Crooks, A. K. Burnett, G. Pratt, C. Fegan, C. Rowntree, P. Brennan and C. Pepper, Blood, 2008, 111, 4681.

20 (a) A. Feula, L. Male and J. S. Fossey, Org. Lett., 2010, 12, 5044-5047; (b) R. M. Archer, M. Hutchby, C. L. Winn, J. S. Fossey and S. D. Bull, Tetrahedron, 2015, 71, 8838-8847; (c) W. D. G. Brittain, B. R. Buckley and J. S. Fossey, Chem. Commun., 2015, 51, 17217-17220; (d) A. Feula, S. S. Dhillon, R. Byravan, M. Sangha, R. Ebanks, M. A. Hama Salih, N. Spencer, L. Male, I. Magyary, W.-P. Deng, F. Müller and J. S. Fossey, Org. Biomol. Chem., 2013, 11, 5083-5093; (e) M. A. Hama Salih, L. Male, N. Spencer and J. S. Fossey, Org. Chem. Front., 2015, 2, 1445-1449; $(f)$ Y. Zhao, H. van Nguyen, L. Male, P. Craven, B. R. Buckley and J. S. Fossey, Organometallics, 2018, 37, 4224-4241.

21 Winterbourne House and Garden, www.winterbourne.org.uk, (accessed 9th December 2018).

22 M. Zoubir, A. Zeroual, M. El Idrissi, A. El Haib, M. Moumou, R. Hammal, N. Mazoir, A. Benharref and A. El Hajbi, J. Mater. Environ. Sci., 2017, 8, 990-996.

23 J. B. Baell and J. W. M. Nissink, ACS Chem. Biol., 2018, 13, 36-44.

24 J. Long, Y.-H. Ding, P.-P. Wang, Q. Zhang and Y. Chen, J. Org. Chem., 2013, 78, 10512-10518.

25 (a) H. Pajouhesh and G. R. Lenz, NeuroRx, 2005, 2, 541-553; (b) J. P. Hughes, S. Rees, S. B. Kalindjian and K. L. Philpott, Br. J. Pharmacol., 2010, 162, 1239-1249; (c) F. Lovering, J. Bikker and C. Humblet, J. Med. Chem., 2009, 52, 6752-6756.

26 See supplementary material for model amination reactions using tulipane as substrate.

27 (a) D.-R. Hwang, Y.-S. Wu, C.-W. Chang, T.-W. Lien, W.-C. Chen, U.-K. Tan, J. T. A. Hsu and H.-P. Hsieh, Bioorg. Med. Chem., 2006, 14, 83-91; (b) H.-P. Hsieh, T.-A. Hsu and D.-R. Hwang, US2004/0229936A1, 2004.

28 P. A. Crooks, C. T. Jordan and X. Wei, US2005/0272716A1, 2005.

29 (a) J. R. Woods, H. Mo, A. A. Bieberich, T. Alavanja and D. A. Colby, J. Med. Chem., 2011, 54, 7934-7941; (b) P. A. Crooks, C. T. Jordan and X. Wei, WO2005/007103A2, 2005.

30 S. Lukas, Curr. Cancer Drug Targets, 2016, 16, 701-709.

31 (a) A. Stacchini, M. Aragno, A. Vallario, A. Alfarano, P. Circosta, D. Gottardi, A. Faldella, G. Rege-Cambrin, U. Thunberg, K. Nilsson and F. Caligaris-Cappio, Leuk. Res., 1999, 23, 127-136; (b) R. Kandaswamy, G. P. Sava, H. E. Speedy, S. Beà, J. I. Martín-Subero, J. B. Studd, G. Migliorini, Philip J. Law, X. S. Puente, D. Martín-García, I. Salaverria, J. Gutiérrez-Abril, C. 
López-Otín, D. Catovsky, J. M. Allan, E. Campo and R. S. Houlston, Cell Rep., 2016, 16, 2061-2067; (c) A. Agathanggelou, E. Smith, N. J. Davies, M. Kwok, A. Zlatanou, C. E. Oldreive, J. Mao, D. Da Costa, S. Yadollahi, T. Perry, P. Kearns, A. Skowronska, E. Yates, H. Parry, P. Hillmen, C. Reverdy, R. Delansorne, S. Paneesha, G. Pratt, P. Moss, A. M. R. Taylor, G. S. Stewart and T. Stankovic, Blood, 2017, 130, 156.

32 (a) M. M. Nociari, A. Shalev, P. Benias and C. Russo, J. Immunol. Methods, 1998, 213, 157-167; (b) G. R. Nakayama, M. C. Caton, M. P. Nova and Z. Parandoosh, J. Immunol. Methods, 1997, 204, 205-208.

33 J. R. Woods, H. Mo, A. A. Bieberich, T. Alavanja and D. A. Colby, MedChemComm, 2013, 4, 27-33.

34 R. S. Obach, Drug Metab. Dispos., 1999, 27, 1350.

35 (a) I. J. Hidalgo, T. J. Raub and R. T. Borchardt, Gastroenterology, 1989, 96, 736-749; (b) Z. Wang, C. E. C. A. Hop, K. H. Leung and J. Pang, J. Mass Spectrom., 2000, 35, 71-76; (c) S. Luo, D. Pal, S. J. Shah, D. Kwatra, K. D. Paturi and A. K. Mitra, Mol. Pharmaceutics, 2010, 7, 412-420.

36 K. D. Freeman-Cook, R. L. Hoffman and T. W. Johnson, Future Med. Chem., 2013, 5, 113-115.

37 T. W. Johnson, R. A. Gallego and M. P. Edwards, J. Med. Chem., 2018, 61, 6401-6420.

38 Compound 2a (DMAPT) has a LipE in the alamarBlue assay of activity against the MEC1 cell line of 3.19.

39 P. Szymanski, M. Markowicz and E. Mikiciuk-Olasik, Int. J. Mol. Sci., 2012, 13, 427-452.

40 (a) C. E. Pollard, N. Abi Gerges, M. H. Bridgland-Taylor, A. Easter, T. G. Hammond and J. P. Valentin, Br. J. Pharmacol., 2010, 159, 12-21; (b) D. Rampe and A. M. Brown, J. Pharmacol. Toxicol. Methods, 2013, 68, 13-22; (c) S. Ekins, W. J. Crumb, R. D. Sarazan, J. H. Wikel and S. A. Wrighton, J. Pharmacol. Exp. Ther., 2002, 301, 427.

41 Z. Zheng, X.-P. Huang, T. J. Mangano, R. Zou, X. Chen, S. A. Zaidi, B. L. Roth, R. C. Stevens and V. Katritch, J. Med. Chem., 2017, 60, 3070-3081.

42 Y. Chen, S. J. O'Connor, D. Gunn, J. Newcom, J. Chen, L. Yi, H.-J. Zhang, L. M. Hunyadi and R. Natero, WO2004/058727A1, 2004.

43 (a) V. D. Nimbarte, H. Murtuza, S. Phaniraj, S. Shrivastava, V. G. M. Naidu, N. Satheesh Kumar and K. R. Atcha, Med. Chem. Res., 2014, 23, 2178-2197; (b) C. Qu, M. Ding, Y. Zhu, Y. Lu, J. Du, M. Miller, J. Tian, J. Zhu, J. Xu, M. Wen, A. G. A. Er-Bu, J. Wang, Y. Xiao, M. Wu, O. B. McManus, M. Li, J. Wu, H.-R. Luo, Z. Cao, B. Shen, H. Wang, M. X. Zhu and X. Hong, J. Med. Chem., 2017, 60, 4680-4692.

44 X. Li, D. T. Payne, B. Ampolu, N. Bland, J. T. Brown, M. J. Dutton, C. A. Fitton, A. Gulliver, L. Hale, D. Hamza, G. Jones, R. Lane, A. G. Leach, L. Male, E. G. Merisor, M. J. Morton,
A. S. Quy, R. Roberts, R. Scarll, T. Schulz-Utermoehl, T. Stankovic, B. Stevenson, J. S. Fossey and A. Agathanggelou, ChemRxiv, 2019, DOI: 10.26434/chemrxiv.7629680.

45 (a) M. Vidal, M. García-Arriagada, M. C. Rezende and M. Domínguez, Synthesis, 2016, 48, 4246-4252; (b) W. Jamal, A. Bari, R. A. Mothana, O. Basudan, M. S. Mohammed and S. W. Ng, Asian J. Chem., 2014, 26, 5183-5185; (c) G. Bryant, Plant Propagation A to Z: Growing Plants for Free, David \& Charles Ltd, 2004; (d) Royal Horticultural Society: Tanacetum parthenium, feverfew, https://www.rhs.org.uk/Plants/17986/iTanacetum-parthenium-i/Details, (accessed 19th December 2018); (e) The Plant List, http://www.theplantlist.org/tpl1.1/ record/gcc-36373, (accessed 11th December 2018); $(f)$ A. Y. Zherebker, D. Airapetyan, A. I. Konstantinov, Y. I. Kostyukevich, A. S. Kononikhin, I. A. Popov, K. V. Zaitsev, E. N. Nikolaev and I. V. Perminova, Analyst, 2015, 140, 4708-4719; $(g)$ G. L. Bolton, e-EROS Encyclopedia of Reagents for Organic Synthesis, 2001; $(h)$ L. Huck, M. Berton, A. de la Hoz, A. Díaz-Ortiz and J. Alcázar, Green Chem., 2017, 19, 1420-1424; (i) F. Wang, J. Li, A. L. Sinn, W. E. Knabe, M. Khanna, I. Jo, J. M. Silver, K. Oh, L. Li, G. E. Sandusky, G. W. Sledge, H. Nakshatri, D. R. Jones, K. E. Pollok and S. O. Meroueh, J. Med. Chem., 2011, 54, 7193-7205; (j) K. E. Bashford, M. B. Burton, S. Cameron, A. L. Cooper, R. D. Hogg, P. D. Kane, D. A. MacManus, C. A. Matrunola, C. J. Moody, A. A. B. Robertson and M. R. Warne, Tetrahedron Lett., 2003, 44, 1627-1629; (k) D. N. Kazulkin and V. S. Kochubey, EP2719696A1, 2011; (l) G. M. Morris, R. Huey, W. Lindstrom, M. F. Sanner, R. K. Belew, D. S. Goodsell and A. J. Olson, J. Comput. Chem., 2009, 30, 2785-2791; (m) O. Trott and A. J. Olson, J. Comput. Chem., 2010, 31, 455-461; (n) G. Xu, Y.-C. Lo, Q. Li, G. Napolitano, X. Wu, X. Jiang, M. Dreano, M. Karin and H. Wu, Nature, 2011, 472, 325; (o) A. J. GarciaPineres, V. Castro, G. Mora, T. J. Schmidt, E. Strunck, H. L. Pahl and I. Merfort, J. Biol. Chem., 2001, 276, 39713-39720; (p) F. W. Goldberg, J. G. Kettle, T. Kogej, M. W. D. Perry and N. P. Tomkinson, Drug Discovery Today, 2015, 20, 11-17; (q) R. Dennington, T. A. Keith and J. M. Millam, GaussView 6, 2016; (r) Y.-Q. Chen, S. Ghosh and G. Ghosh, Nat. Struct. Biol., 1998, 5, 67; (s) J. Meyers, M. Carter, N. Y. Mok and N. Brown, Future Med. Chem., 2016, 8, 1753-1767; $(t)$ N. M. O'Boyle, M. Banck, C. A. James, C. Morley, T. Vandermeersch and G. R. Hutchison, Aust. J. Chem., 2011, 3, 33; (u) N. C. Firth, N. Brown and J. Blagg, J. Chem. Inf. Model., 2012, 52, 2516-2525; (v) P. D. Leeson and A. M. Davis, J. Med. Chem., 2004, 47, 6338-6348.

46 (a) J. S. Fossey and W. D. G. Brittain, Org. Chem. Front., 2015, 2, 101-105; (b) D. T. Payne, J. S. Fossey and R. B. P. Elmes, Supramol. Chem., 2016, 28, 921-931. 